Dept. of Biochemistry,

Animal Health Research Institute,

Mansoura Provincial Laboratory.

\title{
SOME BACTERIOLOGICAL AND BIOCHEMICAL STUDIES ON BUFFALOES AFFECTED WITH RETAINED FETAL MEMBRANE IN DAKAHLIA GOVERNORATE
}

(With 7 Tables)

By

\section{S.A. EL-DESSOUKY; M.M. ABD EL-LATIF* and A.H. MOUSTAFA * \\ *Dept. of Bacteriology, Animal Health Research Institute, Mansoura Provincial Laboratory.}

(Received at 18/3/2006)

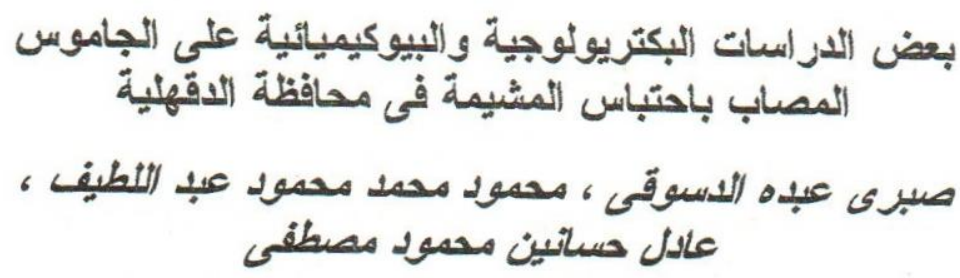

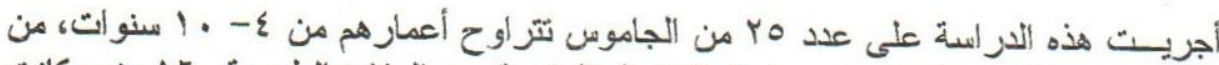

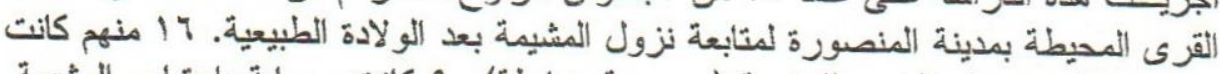

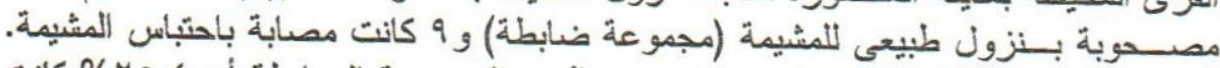

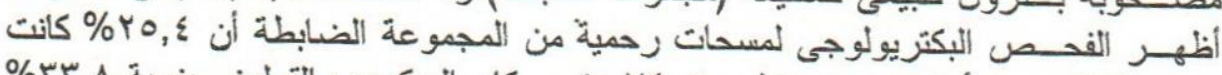

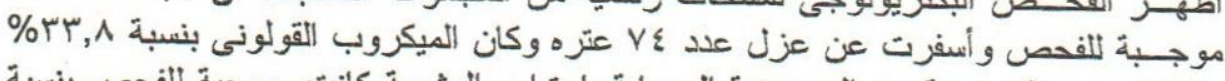

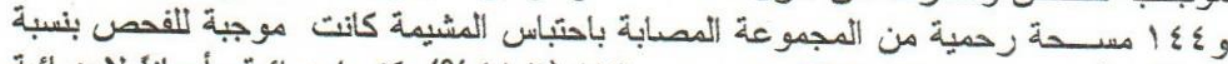

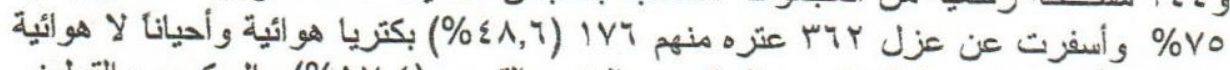

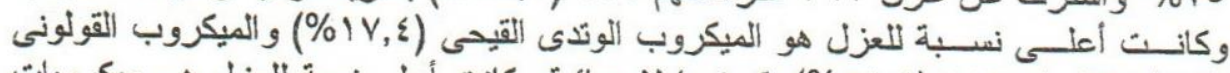

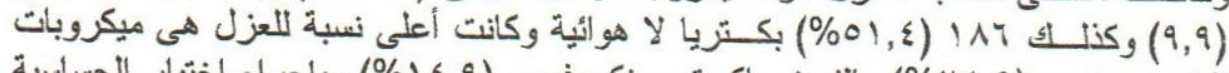

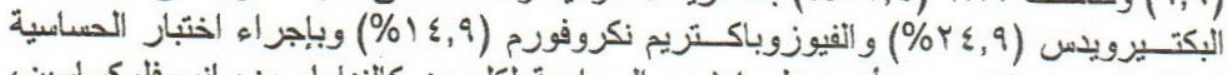

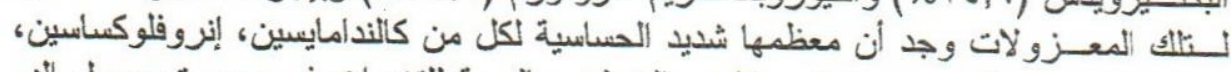

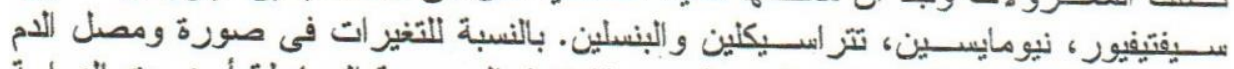

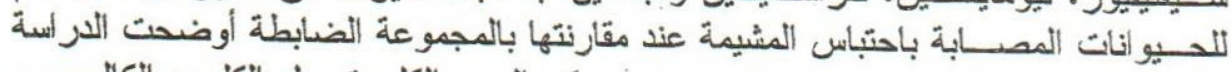

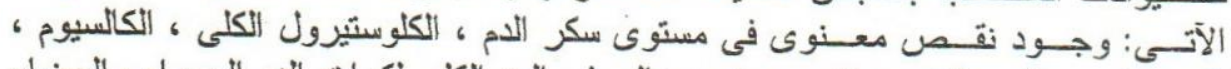

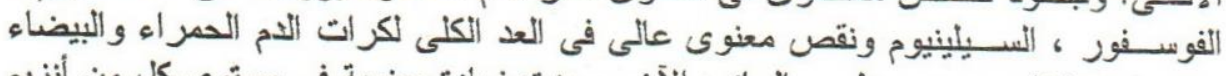

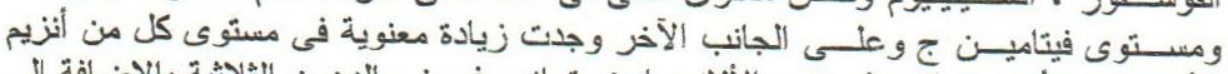

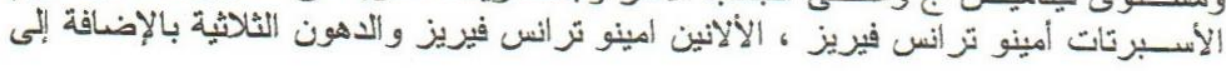




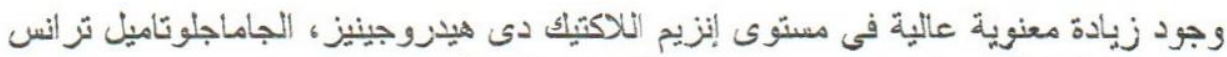

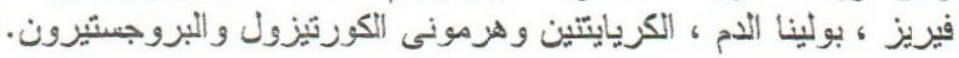

\section{SUMMARY}

A total of 25 buffaloes aged between 4-10 years, from in different villages surrounding Mansoura city to follow fetal membrane drop after normal parturition. Sixteen of them with normal dropped fetal membrane (control) and nine with retained fetal membrane were used in this study. For the first 8 weeks after parturition each buffaloe was subjected to clinical examination, bacteriological examination and haematological and biochemical studies. Bacteriological examination of 256 uterine swabs of control buffaloes showed that 65 (24.4\%) swabs were bacteriologically positive. Yielded 74 isolates mainly E. coli $(33.8 \%)$. Meanwhile for retained fetal membrane buffaloes 144 uterine swabs, $108(75.0 \%)$ were bacteriologically positive with $1.9 \%$ pure single aerobic and faculitative anaerobic cultures; $14.8 \%$ pure single anaerobic and $83.3 \%$ mixed cultures. They yielded 362 isolates comprising $176(48.6 \%)$ aerobic and faculitative anaerobic bacteria with the most predominant ones were A. pyogenes $(17.4 \%)$ and E. coli $(9.9 \%)$ and obligate anaerobic bacteria $186(51.4 \%)$ mainly Bacteroides Spp. (24.9\%) and Fusobacterium necrophorum (14.9\%). Sensitivity test for those isolated bacteria revealed that the most of isolates were highly sensitive to clindamycin, enrofloxacin, ceftioufur, neomycin, tetracycline and penicillin. The changes in blood and serum of retained fetal membrane buffaloes when compared with control group, revealed that: Presence of significant decrease in the level of glucose \& total cholesterol \& calcium \& phosphorus \& selenium and high significant decrease in the total count of erthrocytes, leucocytes and vitamin $C$ level. On the other side significant increase was observed in the level of S. AST, S.ALT and triglyceride. High significant increase were noticed in S.LDH, $\gamma \mathrm{GT}$, blood urea, Creatinine, cortisol and progesterone levels.

Key words: Placenta, fetal membrane, buffaloes, bacteriology, antibiotic sensitivity.

\section{INTRODUCTION}

Retained fetal membrane (RFM) with subsequent uterine infection, endometritis, reduction in milk yield and lower conception rates are a common problems in dairy animals. (Hemingway, 2003). Such problems associated with activities of microorganisms, the intrauterine microorganisms which isolated during disturbances of the 
post partum uterus have been described in several studies (Fredriksson et al., 1985 and Cohen et al., 1996). The bacteriological examination of the uteri of dairy cattle with RFM has been studied aerobically, but most of aerobic bacteria have little effect on fertility and Actinomyces pyogenes, E. coli, Bacteroides spp. and Fusobacterium necrophorum were the major isolated bacterial pathogens (Konigsson et al., 2001 and Maarouf and El-Bealawy 2004). Since now bacteriological surverys of both human and bovine uteri indicated that, they are anaerobic environment in which mixed bacteria populations are common. (Ruder et al., 1981). More recently research workers suggested that there were a synergistic relationship between A. pyogenes, Bacteroides spp. and F. necrophorum in producing infertility (Cohen et al., 1996 and Mateus et al., 2002). The condition is characterized by a large number of fetal chorionic epithelial cells undergoing apoptosis immediately after the expulsion of the fetus a consequence of diminished blood supply to the uterus (Boos et al., 2003). Retained fetal membrane in dairy animals depend on some factors as age of the dam, season of calving, twining, hormonal impalance and nutritional deficinces (El-hanafy, 1998 and Ahmed et al., 2004). Some researchers have concluded that this condition is a result of metabolic disturbances during the preparturition period. These disturbances are related to the negative energy balance (Bertics et al., 1992). Moreover vascular changes and utrine contractions has been found to play a role in placental release (Laven and Peters 1996).

There fore the present study was planned to:

- Determine some aerobic and anaerobic bacteria that could be recovered from the post partum uterus of buffaloes with RFM and their relationship to uterine infections.

- Invitro antibiotic sensitivity against the isolated strains.

- Variations in some haematological and biochemical constituents associated with RFM in buffaloes.

\section{MATERIALS and METHODS}

\section{Animals:}

A total number of 25 clinically healthy buffaloes aged between 4-10 years, reared in different villages surrounding Mansoura city were closely observed after normal parturition for placental drop. All animals were not treated. with any drug. sixteen of them with normal dropped fetal membrane within 12 hours post partum (control) Roberts (1986) and nine buffaloes with RFM kept for used in this study for the first 8-weeks after calving each buffaloe was subjected to clinical 
examination vaginally and rectally (RFM buffaloes showed discolored vulval membranes, foul smelling discharge, inappetence and decreased milk yieid). Two uterine swabs were collected weekly from each buffaloe Noakes et al., (1989).

\section{Bacteriological examination:}

For bacteriological examination 256 swabs from normal control buffaloes and 144 from RFM ones. These swabs were immediately aseptically inoculated in thioglycolate medium and nutrient broth and directly transported to the laboratory with 2-4 hours for bacteriological examination. The broth was incubated aerobically and anaerobically at $37^{\circ} \mathrm{C}$ for $24 \mathrm{hr}$., then subcultures were made by streaking on the following media: nutrient agar, MacConkey agar, blood agar and chocalate agar. The plates were incubated at $37^{\circ} \mathrm{C}$ aerobically and anaerobically for 2 to 7 days then subcultured for colonies purification. The purified colonies were identified morphologically and biochemically according to Holt et al., (1994) and Quinn et al., (1994).

\section{In vitro antibiotic sensitivity test:}

The disc diffusion technique was performed on isolated bacteria from infected cases according to Finegold and Martin (1982). Ten chemotherapeutic discs kindly supplied by Oxoid and namally, Clindamycin, Enrofloxacin, Neomycin, Ceftiofur, Penicillin, Tetracycline, Ciprofloxacin, Ampicillin, Streptomycin and Gentamycin.

\section{Blood samples:}

Two blood samples were collected from each animal via jugular vein puncture. The first samples were whole blood collected in vacutainer tubes containing EDTA as anticoagulant and were used for haematological studies according to Jain (2000). The second samples were collected in centrifuge tubes and allowed to clot at $73^{\circ} \mathrm{C}$ and then non haemlysed blood serum was separated used for measuring some biochemical constituents such as glucose, LDH, $\gamma \mathrm{GT}$, ALT, Blood urea, creatinine, total cholesterol and triglyceride using commercial diagnostic kits accoroding to Trinder (1969); Kachmar and Moss (1976); Tietz (1994); Reitman and Frankel (1957); Fawcett and Scott (1960); Husdan and Rapoport (1968), Allain et al., (1974); Fossati and prencipe (1982) respectively. Vitamin $\mathrm{C}$ was determined after the method described by (Lowry et al 1945) by using spectrophotometer. Progesterone was measured by RIA using coat-A count progesterone kite (diagnostic products, Los Angeles CA) according to (Kubasik, 1984). Selenium concentration was determined using atomic absorption spectrophotometer according to (Mestek et al., 1997). Cortisol level was 
also assayed RIA (Abraham, 1981). Serum calcium and inorganic phosphorous was determined by using commercial diagnostic kits according to (Gindler and king, 1972) and Goidenberg, 1966) respectively.

\section{Statistical analysis:}

The statistical analysis $\mathrm{T}$ test according to (Snedecor and Cochran 1982) by using slide write plus for windows version 3.0 WSWP.

\section{RESULTS}

The results of the present study were illustrated in Tables (1-7).

Table 1: Bacteriological examination of both normally dropped fetal membrane and R.F.M. buffaloes.

\begin{tabular}{|c|c|c|c|c|c|c|c|c|c|c|c|c|}
\hline \multirow{3}{*}{$\begin{array}{l}\text { Case of } \\
\text { Animals }\end{array}$} & \multirow{3}{*}{$\begin{array}{l}\text { No. of } \\
\text { animals }\end{array}$} & \multirow{3}{*}{$\begin{array}{l}\text { No. of } \\
\text { swabs }\end{array}$} & \multirow{2}{*}{\multicolumn{2}{|c|}{$\begin{array}{c}\text { Negative } \\
\text { swabs }\end{array}$}} & \multirow{2}{*}{\multicolumn{2}{|c|}{ Positive swabs }} & \multicolumn{4}{|c|}{ Pure single cultures } & \multirow{2}{*}{\multicolumn{2}{|c|}{ Mixed cultures }} \\
\hline & & & & & & & \multicolumn{2}{|c|}{$\begin{array}{c}\text { Aerobic and } \\
\text { faculitative } \\
\text { anaerobic bacteria }\end{array}$} & \multicolumn{2}{|c|}{$\begin{array}{l}\text { Obligate } \\
\text { anaerobic } \\
\text { bacteria }\end{array}$} & & \\
\hline & & & No. & $\%$ & No. & $\%$ & No. & $\%$ & No. & $\%$ & No. & $\%$ \\
\hline Normal & 16 & 256 & 191 & 74.6 & 65 & 25.4 & 7 & 10.8 & 0 & 0.0 & 58 & 89.2 \\
\hline RFM & 9 & 144 & 36 & 25.0 & 108 & 75.0 & 2 & 1.9 & 16 & 14.8 & 90 & 83.3 \\
\hline
\end{tabular}

Table 2: Percentage of bacterial species isolated from 65 positive swabs of buffaloes with normal dropped fetal membrane and 108 positive swabs of RFM buffaloes.

\begin{tabular}{|c|c|c|c|c|}
\hline \multirow[t]{2}{*}{ Bacterial species } & \multicolumn{2}{|c|}{$\begin{array}{c}\text { Buffaloes with } \\
\text { normal dropped F.M. }\end{array}$} & \multicolumn{2}{|c|}{$\begin{array}{l}\text { Buffaloes with } \\
\text { R.F.M. }\end{array}$} \\
\hline & No. & $\% \quad *$ & No. & $\% *$ \\
\hline I- Aerobic and faculitative anaerobes: & 62 & 83.8 & 176 & 48.6 \\
\hline A. pyogenes. & 0 & 0.0 & 63 & 17.4 \\
\hline E. coli. & 25 & 33.8 & 36 & 9.9 \\
\hline Staph. Aureus & 7 & 9.4 & 11 & 3.0 \\
\hline Strept. Pyogenes & 0 & 0.0 & 22 & 6.1 \\
\hline Strept. Faecalis & 15 & 20.3 & 0 & 0.0 \\
\hline Proteus spp. & 15 & 20.3 & 21 & 5.8 \\
\hline Citrobacter freundii & 0 & 0.0 & 13 & 3.6 \\
\hline Klebsilla pneumonae & 0 & 0.0 & 10 & 2.8 \\
\hline II- Obligate anaerobe: & 12 & 16.2 & 186 & 51.4 \\
\hline Bacteriodes spp. & 9 & 12.2 & 90 & 24.9 \\
\hline Fusobacterium necrophorum & 0 & 0.0 & 54 & 14.9 \\
\hline Clostridium perfringenes & 3 & 4.0 & 8 & 2.2 \\
\hline Peptostreptócoccus spp. & 0 & 0.0 & 25 & 6.9 \\
\hline Eubacterium lentum & 0 & 0.0 & 9 & 2.5 \\
\hline Total & 74 & 100.0 & 362 & 100.0 \\
\hline
\end{tabular}

* Percentage in relation to total organisms in each group alone. 
Assiut Vet. Med. J. Vol. 52 No. 109 April 2006

$\infty$

을

రิ

$\frac{0}{5}$

궁

(2)

크

告 $\simeq$ ஸे

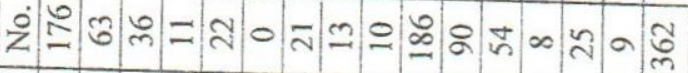

\section{z}

০

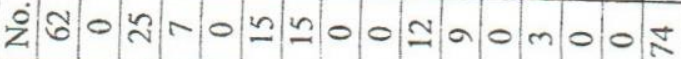

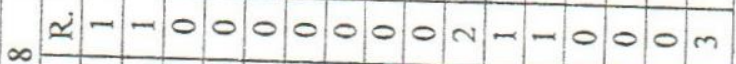

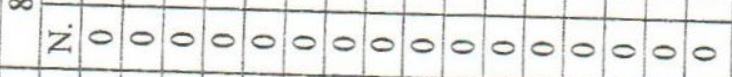

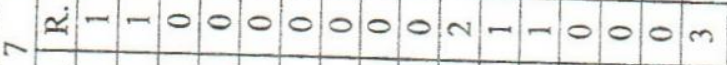

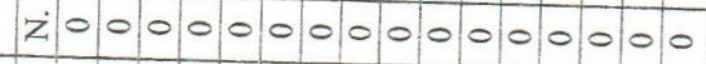

6

$\approx m m 00000000$

్ㅡㄹ

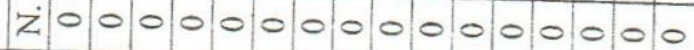

응 $n$

के

$\therefore m$ m 00000000000000

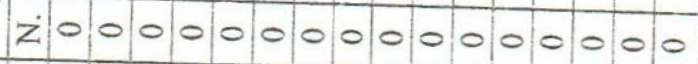

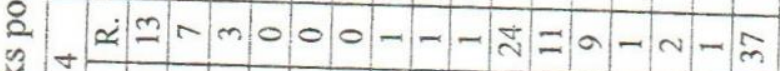

$\frac{1}{4}$

$>$

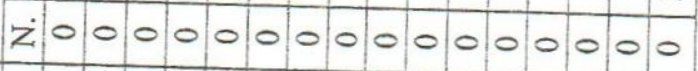

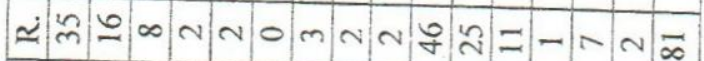

m

$z 0000000000000000$

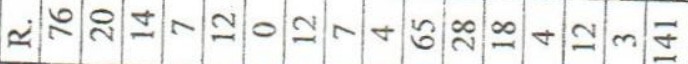

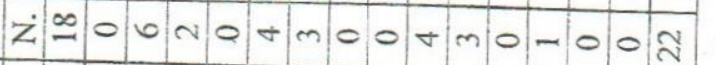

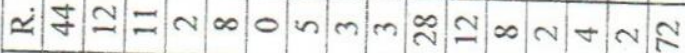

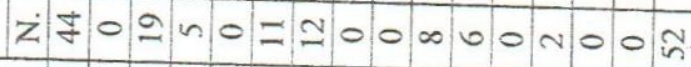

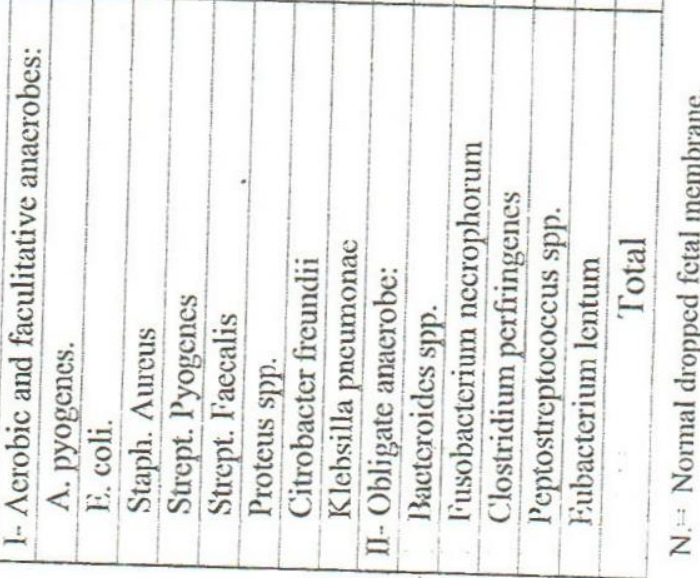




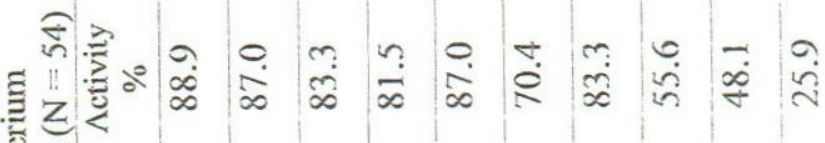

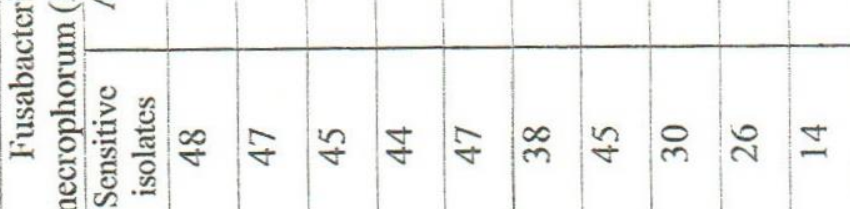

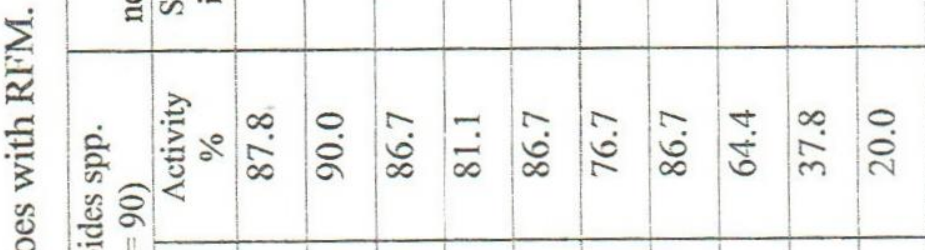

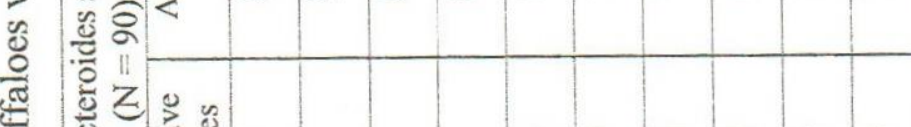

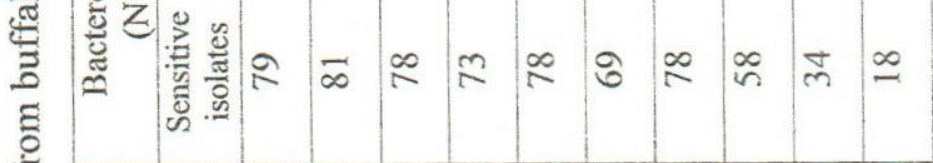

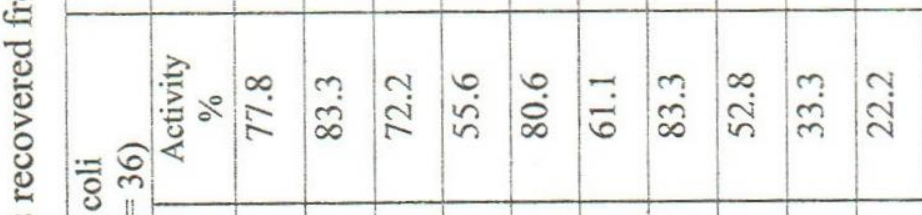

疍

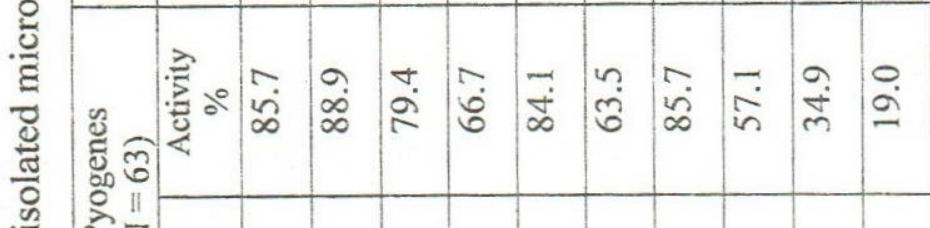

ह

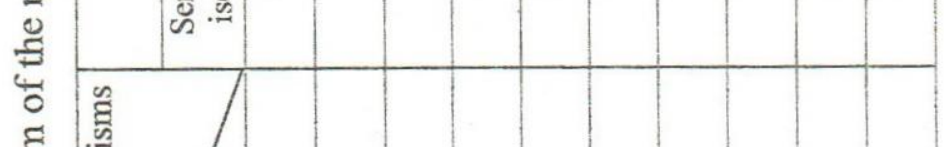

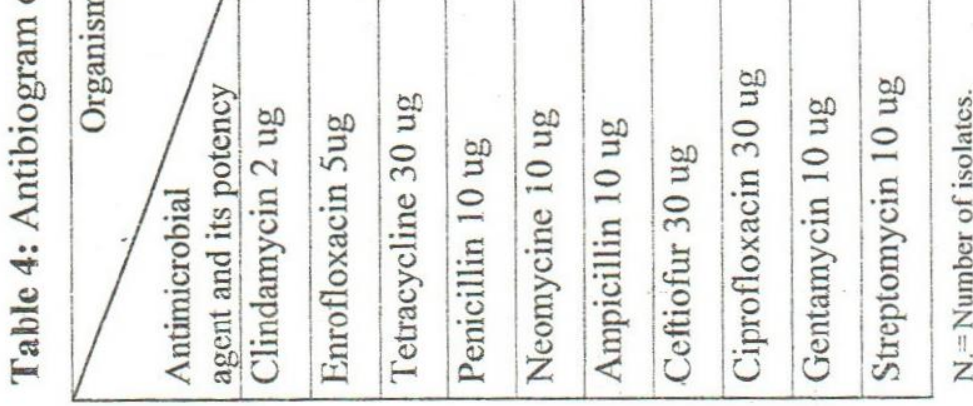




\section{Assiut Vet. Med. J. Vol. 52 No. 109 April 2006}

Table 5: Mean values of some haematological parameters of buffaloes with retained fetal membrane in comparison with normally dropped ones.

\begin{tabular}{|c|c|c|}
\hline Parameters $\quad$ Item & Control group & $\begin{array}{c}\text { Retained fetal } \\
\text { membrane group }\end{array}$ \\
\hline Total RBCs $\left(\times 10^{6} / \mathrm{mm}^{3}\right)$ & $6.63 \pm 0.17$ & $5.78 \pm 0.13 \downarrow^{* *}$ \\
\hline $\mathrm{Hb}(\mathrm{g} / \mathrm{dL})$ & $11.09 \pm 0.21$ & $10.95 \pm 0.26 \downarrow$ N.S \\
\hline PCV (\%) & $33.11 \pm 0.81$ & $30.26 \pm 1.14 \downarrow \mathrm{NSS}$ \\
\hline Total WBCs $\left(\times 10^{3} / \mathrm{mm}^{3}\right)$ & $9.63 \pm 0.20$ & $8.32 \pm 0.27 \downarrow^{* *}$ \\
\hline
\end{tabular}

N.S: Non significant.

Table 6: Mean values of some liver and kidney functions of buffaloes with retained fetal membrane in comparison with normally dropped ones.

\begin{tabular}{|c|c|c|}
\hline Parameters & Control group & $\begin{array}{l}\text { Retained fetal membrane } \\
\text { group }\end{array}$ \\
\hline Glucose (mg/dl) & $51.37 \pm 1.42$ & $45.13 \pm \downarrow^{*}$ \\
\hline $\mathrm{LDH}(\mathrm{IU} / \mathrm{L})$ & $151.81 \pm 1.88$ & $161.14 \pm 2.37 \uparrow^{* *}$ \\
\hline$\gamma \mathrm{GT}(\mathrm{IU} / \mathrm{L})$ & $9.60 \pm 0.25$ & $11.20 \pm 0.32 \uparrow^{* *}$ \\
\hline $\mathrm{AST}(\mathrm{IU} / \mathrm{L})$ & $11.19 \pm 0.33$ & $12.89 \pm 0.50 \uparrow^{*}$ \\
\hline ALT (IU/L) & $7.29 \pm 0.37$ & $8.94 \pm 0.44 \uparrow^{*}$ \\
\hline Blood urea $(\mathrm{mg} / \mathrm{dL})$ & $24.48 \pm 1.35$ & $31.19 \pm 1.69 \uparrow^{* *}$ \\
\hline Creatinine (mg/dL) & $0.97 \pm 0.08$ & $1.82 \pm 0.21 \uparrow^{* *}$ \\
\hline
\end{tabular}

** Significant at $\mathrm{p}<0.01$.

Table 7: Mean values of some biochemical parameters of buffaloes with retained fetal membrane in comparison with normally dropped ones.

\begin{tabular}{|c|c|c|}
\hline $\begin{array}{ll}\text { Parameters } & \text { Item } \\
\end{array}$ & Control group & $\begin{array}{l}\text { Retained fetal } \\
\text { membrane group }\end{array}$ \\
\hline Total cholesterol $(\mathrm{mg} / \mathrm{dl})$ & $84.27 \pm 1.45$ & $78.11 \pm 1.77 \downarrow^{*}$ \\
\hline Triglyceride & $28.52 \pm 1.02$ & $33.27 \pm 1.41 \uparrow^{*}$ \\
\hline Cortisol $(\mathrm{ng} / \mathrm{ml})$ & $0.82 \pm 0.05$ & $1.25 \pm 0.10 \uparrow * *$ \\
\hline Progesterone $(\mathrm{ng} / \mathrm{ml})$ & $0.77 \pm 0.11$ & $1.38 \pm 0.16 \uparrow * *$ \\
\hline Calcium (mg/dl) & $10.91 \pm 0.20$ & $9.86 \pm 0.30 \downarrow *$ \\
\hline In organic phoshprus (mg/dl) & $5.37 \pm 0.19$ & $4.33 \pm 0.31 \downarrow *$ \\
\hline Selenium (mg/dl) & $3.63 \pm 0.26$ & $2.53 \pm 0.31 \downarrow^{*}$ \\
\hline Vitamin C (mg/l) & $2.61 \pm 0.13$ & $1.50 \pm 0.25 \downarrow * *$ \\
\hline
\end{tabular}

${ }^{* *}$ Significant at $p<0.01$. 


\section{DISCUSSION}

Uterine infections in dairy animals with retained fetal membrane were common problems as recorded by konigsson et al., (2001).

The obtained results for bacteriological examination (Table 1) of normal dropped fetal membrane buffaloes (control) showed that 65 $(25.4 \%)$ biopsies were positive which yielded 74 isolates (Table 2) mainly E. coli $(33.8 \%)$ and the isolated bacteria rapidly decreased after the first week and disappeared after the second week (Table 3). Nearly similar results were reported by Maarouf and El-Bealaw (2004). The results of bacteriological examination of RFM buffaloes (Table 1) showed that $108(75.0 \%)$ samples were bacteriologically positive with $1.9 \%$ pure single aerobic and faculitative anaerobic cultures, $14.8 \%$ pure single anaerobic and $83.3 \%$ mixed cultures. The positive samples (Table 2) yielded 362 isolates, comprising $176(48.6 \%)$ aerobic and facultative anaerobic bacteria and $186(51.4 \%)$ obligate anaerobic bacteria. The most predominant aerobic isolates were A. pyogenes $(17.4 \%)$ and E. coil $(9.9 \%)$ where in anaerobic bacteria, Bacteroides spp. $(24.9 \%)$ and Fusobacterium necrophorum (14.9\%) were the predominant types (Table, 2). These results agreed with those previously recorded by Holt et al., (1989) Laven and peters (1996) and Dhaliwal et al., (2001). The obtained results (Table 3 ) revealed that the number of isolated bacteria from RFM buffaloes were firstly increased during the first two weeks, this attributed to decreased in No. of neutrophils during this time. (Abd El-Aziz et al., 2002), then progressively decreased during the subsequent weeks and no bacteria were isolated after the end of the $6^{\text {th }}$ week, except A. pyogenes, Bacteroides, spp. and Fusbactarium necrophorum were isolated in a mixed culture in $7^{\text {th }}$ and $8^{\text {th }}$ week. This result agreed with that reported by Dhaliwal et al., (2001). Therefore this findings showed that these organisms could be classified as primary pathogens in dairy cattles with RFM while other pathogens may be due to unhygienic conditions during the handling of parturient buffaloes. These result agreed with that reported by Dhaliwal et al., (2001). On other hand, Holt et al., (1989) cited that E. coli, haemolytic streptococci and $\mathrm{A}$. pyogenes were the predominant pathogens responsible for this problem.

In vitro, the susceptibility distribution of most isolated pathogens to different antibiotic is represented in Table (4), most of isolates were highly sensitive to clindamycin, enrofloxacin, ceftioufur, neomycin, tetracycline and penicillin. These results similar with those mentioned by 
Van den Bogaard et al., (1992), Cohen et al., (1996), Konigsson et al., (2001) and Scott et al., (2005).

The present findings of the erythrograme parameters, (Table 5) revealed that the RFM group showed highly significant $(\mathrm{P}<0.01)$ decrease in total RBCs count, while non significant decrease in haemoglobin and packed cell volume values were noticed. These results were supported by those of (Srinivas et al., 1999 and Abdel Aziz et al., 2002). This reduction in RBCs count may be due to depressed appetite. (Table 5) showed that presence of high significant $(\mathrm{P}<0.01)$ leucopenia in RFM group, than control ones. This leucopenia may be due to high concentration of leukocytes that infiltrate the endmetrium post calving. This result agreed with the result of (Kudlac et al., 1995) in cows. Dealing with the glucose mean values Table (6) showed that there was significant $(\mathrm{P}<0.05)$ decrease below the control level. The decreased glucose level in (RFM) group could be attributed to energy deficiency causing weakness and inadequate strength to normal calving including normal expulsion of the placenta. This result was supported by those of (Sabry et al., 1997 and Patel et al., 1999).

It is evident from Table (6) that there was high significant $(\mathrm{P}<0.01)$ increase in $\mathrm{LDH}$ and $\gamma \mathrm{GT}$ activity in $(\mathrm{RFM})$ group when compared with the control group. This result was in accordance with (Kudlac et al., 1995 and Kandil et al., 2002). Peter et al., (1987) found that cows with afterbirth retention had, significantly higher activity of LDH, which lead excessive lactic acid production results in metabolic acidosis. Concerning $\gamma$ GT (Kankfer and Maj 1997) said that the changes in this enzyme may indicate to an imbalance in free radicals generation and neutralization. Table (6) revealed that there were significant $(\mathrm{P}<0.05)$ increase in AST and ALT level over the control level. These results coincided with those reported by (Laven and Peters 1996) and (Srinivas et al., 1999) who attributed these changes to bacterial infection and their toxins.

In the present study there were high significant $(\mathrm{P}<0.01)$ increase in blood urea and creatinine levels in RFM Table (6). These results were similar to those reported by (Maarouf and El-Bealawy, 2004) whose attributed such changes perhaps due to presence of several pathogenic bacteria which may caused nephritis in cows.

As shown from the results given in Table (7) we found that serum cholesterol had an opposite patteren to triglyceride and showed significant $(\mathrm{P}<0.05)$ decrease in its levels in comparison to control group. The reduction in cholesterol level could be attributed to its 
utilization for synthesis of progesterone which more available in retained fetal membrane. This agreed with the results reported by (Kandeil et al., 2002). while the elevation in triglycerides level could be explained by the negative energy balance caused mobilization of the body fat. As consequence the animal accumulated greater amount of triacylglycerol in the liver. This accumulation was associated with an increase in the interval from parturition to the first ovulation (Rukkuramusk et al., 1999).

With regard to cortisol and progesterone levels Table (7) indicated high significant $(\mathrm{P}<0.01)$ increase in $\mathrm{RFM}$ group than control ones. Similar results were reported in cows with placental retention, regarding progesterone (Sabry et al., 1997), cortisol (Laven and Peters, 1996). This noticeable increase may be due to the endocrine imbalance in prepartum period and this predispose for myometrial dysfunction and placental retention. The results displayed in Table (7) revealed that calcium and in organic phosphorus levels decreased significantly $(\mathrm{P}<0.05)$ in $(\mathrm{RFM})$ group when compared with control one. These results closely fitted with results in cattle obtained by (Younis, 1990 and Ahmed et al., 1999). Arthur et al., (1992) concluded that the lower levels of calcium and phosphorus in (RFM) group may be due to excessive mobilization of these cations to the fetus during the late stage of pregnancy as well as due to the increased draing of calcium through colostrum at the onset of lactation. The results of the present investigation showed significant $(\mathrm{P}<0.05)$ decrease in selenium level in RFM cases which present in Table (7). This result goes hand in hand with those recorded previously by (El-Khadrawy and El-Ekhnawy 2005). Ahmed et al., (1999) recorded that inadequate concentrations of selenium and vitamin $\mathrm{E}$ in the diet increased oxidative stress, increased production of lipid peroxidase and in turn increased the incidence of RFM.

The data illustrated in Table (7) indicated highly significant $(\mathrm{P}<0.01)$ decrease of vitamin $\mathrm{C}$ level in $(\mathrm{RFM})$ group if compared to control group. The marked reduction in vitamin $\mathrm{C}$ level may be due to the use of this vitamin during the pathogenesis of this disease, where vitamin $\mathrm{C}$ may be consumed as antioxidant against the oxidative stress that elevated during inflammation (Friedrich, 1988). Moreover vitamin $\mathrm{C}$ may be used for biosynthesis of collagen in the damaged tissues (Barnes 1975). The result in the present work agreed with those reported by (Kandeil et al., 2002). 
Finally, we can concluded that: RFM in buffaloes is a serious problem, A. pyogenes, E. coli, F. necrophorum and Bacteroides spp. are the predominant bacteria and primary pathogens in buffaloes with RFM during the post partum period and the bovine uterus is anaerobic environment. So the selection of antibacterial agents for controlling RFM should be based on their effectiveness in anaerobic environment also their inhibitory effect on these bacteria beside good hygiene and good cleaning. There is a correlation between the concentration of blood constituents especially calcium, phosphorus, selenium and vitamin $\mathrm{C}$ and the occurrence of this syndrome. So this permitting correction of these deficiency.

\section{REFERENCES}

Abdel Aziz, M.Z.; Manal, G. and Fadl allah, El-Bakhmy, A.S.M. (2002): Some clinico-pathological studies on buffalo cows affected with retained fetal membranes. G. Egypt. Vet. Med. Ass., 62(5): $73-$ 84.

Abraham, G.E. (1981): Radioassay system. In: Clinical Endocrinology. Basell. Marcel Dekker, PP. 475 - 529.

Ahmed, W.A.; El - Ekhnawy, K.L.; Dessouky, H.M.; Zaabal, M.M. and Ahmed, Y.F. (1999): Investigation on retained fetal membranes in Friesian cows in Egypt. Egypt. J. comp. path. and clinical path., 12: 160.

Ahmed, W.M.; El-Ekhnawy, K.I.; El-Nattat, W.S.; Dessouky, H.M. and El-Khadrawy, H.H. (2004): Investigation on calvingassociated problems in a Friesian herd in Egypt with special reference to some prophylactic trials. J. Basic physiol., 3: $65-$ 87.

Allain, C.C; poon, L.S.; Chan, C.S.G.; Richmond, W. and Fu, P.C. (1974): "Enzymatic determination of total serum cholesterol. "Clin.Chem., 20: 470-475.

Arthur, G.H.; Nokaes, D.E. and person, H. (1992): "Veterinary reproduction and obstetrics" $6^{\text {th }}$ Ed., Bailliere Tindall, Londan.

Barnes, M.J. (1975): "Function of Ascorbic acid in Collagen metabolism" Ann. N.Y. Acad. Sci, 258: $264-277$.

Bertics, S.J.; Grummer, R.R.; Cadorninga Valino, C. and Stoddard, E.E. (1992): "Effect of prepartum dry matter intake on liver triglyceride concentration in early lactation. J. Dairy Sci, 75: 1914. 
Boss, A.; Janssen, V. and Muller, C. (2003): Proliferation and apoptosis in bovine placentomes during pregnancy and around induced and spontaneous parturition as well as cows retaining the fetal membranes. Reproductioin, 126: $469-480$.

Cohen, R.O.; Colonder, R.; Ziv, G. and Keness, J. (1996): Isolation and antimicrobial susceptibility of obligate anaerobic bacteria recovered from the uteri of dairy cows with retained fetal membranes and post parturient endometritis zentralbl. Veterinarmed [B], 43 (4): $193-199$.

Dhaliwal, G.S.; Murray, R.D. and Woldehiwet, Z. (2001): Some aspects of immunology of the bovine uterus related to treatment for endometritis. Anim. Reprod. Sci., 67 (3-4): 135-152.

El-Hanafi, A.A. (1998): The effect of adding some vitamins and minerals on performance of lactating buffaloes. M. V. Sc., thesis, (Agric. Sci.), Ain Shams Univ.

El-Khadrawy, H.H. and El-Ekhnawy, K.I. (2005): Effect of placental retention on some Antioxidant concentrations and hormone levels, and subsequent reproductive performance of Friesian cows in Egypt. J. Egypt. Vet. Med. Assoc., 65 (3): 79 - 87.

Fawcett, J.K. and Scott, J.E. (1960): colorimetric determination of urea. J. Clin, Path., 13: 156.

Finegold, S.M. and Martin, W.J. (1982): "Diagnostic Microbiology", $6^{\text {th }}$ Edn., C.V. Mosby Co. St. Louis, Toronto, London.

Fossati, P. and Prencipe, L. (1982): " Serum triglycerides determination colourimetracally with an enzyme that produces hydrogen peroxide . Clin . Chem., 28: $2077-2080$.

Fredriksson, G.; Kindahl, H.; Sandstedt, K. and Edquist, L.E. (1985): Intrauterine bacterial findings and release of PGF in the postpartum dairy cow zbl. Vet. Med. A32, $368-380$.

Frieldrich, W. (1988): "Vitamins" Walter de Grader Publ. New York.

Gindler, M.E. and King, J.D. (1972): Rapid colorimetric determination of calcium in fluids with methyl thymol blue. Am. J. clin. Path., 58: 376.

Goldenberg, H. (1966): Determination of inorganic phosphorus. Clin. Chem., 12: 871.

Hemingway, R.C. (2003): the influences of dietary intakes and supplementation with selenium and vitamin $\mathrm{E}$ on reproduction diseases and reproductive efficiency in cattle and sheep. Vet. Res. Communications., 27: $159-174$. 
Holt, J.G.; Krieg, N.R.; Sneath, P.H.A.; Staley, J.T. and Williams, S.T. (1994): Bergey's Manual of Determinative Bacteriology, $9^{\text {th }}$ ed. Williams and Wilkins Co. Baltimiore, PP. 299.

Holt, L.C.; Whittier, W.D.; Gwazdanskas, F.C.; Vinson, W.E. and Sponenberg, P.S. (1989): Involution, Pathology and histology of the uterus in dairy cattle with retained placenta and uterine discharge following GnRH. Anim. Reprod. Sci., 21: 11-23.

Husdan, H. and Rapoport, F. (1968): Estimation of creatinine by the Jaffe reaction. A comparison of three methods. Clin. Chem., 14 (3): $222-238$.

Jain, N.C. (2000): Schalm's Veterinary Haematology, $8^{\text {th }}$ Ed. Lea \& Febiger, Philadelphia, USA.

Kachmar, J.F. and Moss, D.W. (1976): In Fundamentals of Clinical Chemistry, $2^{\text {nd }}$ ed., NW Tietz., Editor. WB.Saunders, Philadelphia, P. 652.

Kandil, M.A.; Amin, K.A. and Ali, K.M. (2002): Comparative biochemical studies between retained and non retained placenta in cow and Buffalo. J. Egypt. Vet. Med. Ass., 62(4): 255 - 264.

Kankofer, M. and Maj, J.G. (1997): Enzyme activities in placental tissues from cow with and without retained fetal membranes.

Dtsch Tierartl Wochenschr, 104(1): 466-472.

Konigsson, K; Gustafsson, H.; Gunnarsson, A. and Kindahl, H. (2001): Clinical and bacteriological aspects on the use of exytetracycline and flunixin in primiparous cows with induced retained placenta and post partal endometritis. Reprod Domest Anim. 36(5): $247-$ 256.

Kubasik, N.P. (1984): " Evaluation of direct solid phase radioimmunoassay for progesterone". Clin. Chem.., 30: 285-286.

Kudlac, E.; Sakaur, M. and Canderie, J. (1995): Metabolic profile in the peripartum period of cows with and without placental retention. Vet. Med, 40 (7): $201-207$.

Laven, R.A. and Peters, A.R. (1996): Bovine Retained placenta: etiology, pathogenesis and economic loss " Vet. Rec. Nov 9; 139(19): $465-471$.

Lowry, O.H.; Lopez, J.A. and bessey, O.A. (1945): Determination of vitamin C. J. boil. Chem.. 6: 606 - 609.

Maarouf, A.A. and El-Bealawy, M.A. (2004): Bacteriological and biochemical studies on cows with retained placenta, Zag. Vet. J., 32(1): $28-36$. 
Mateus, L.; da Costal, L.; Bernardo, F. and Silva, J.R. (2002): Influence of puerperal uterine infection on uterine involution and postpartum ovarian activity in dairy cows. Reprod Domest Anim. 37 (1): 31 35 .

Mestek, O.; Suchananek, M.; Vodickova, Z.Z.; Zemanova, B. and Zima, T. (1997): Comparison of the suitability of various atomic spectroscopic techniques for the determination of selenium in human whole blood. J. Analytical Atomic Sepectrometry, 12: 85 -89 .

Noakes, D.E.; Till, D. and Smith, G.R. (1989): Bovine uterine flora postpartum, A comprison of swabbing and biopsy, Vet. Rec., 124: $563-564$.

Patel, R.D.; Nema, S.P.; Shella Tiwri and Chouhan, R.A. (1999): Biochemical changes associated with retention of fetal memberane in buffaloes. Indian J. of Animal Reproduction., 20 (1) $35-39$.

Peter, A.T.; Bosu, W.T.; Mac williams, P. and Gallagher, S. (1987): "Peripartal changes in serum alkaline phosphatase activity and lactate dehydrogenase activity in dairy cows" Can. J. Vet. Res., 51 (4): 521-524.

Quinn, P.J.; Carter, M.S.; Markyl, B. and Carter, G.R. (1994): Clinical Vet. Microbiology Mosby - year Book - Europe Limited.

Reitman, S. and Frankel, S. (1957): "Colorimetric determination of glutamic transaminase". Am. J. Clin. Path., 28: 56-60.

Roberts, S.J. (1986): "Veterinary obstetrics and genital diseases" $3^{\text {rd }}$ Ed. CBS. India.

Ruder, C.A.; Sasser, R.G.; Williams, R.J.; Ely, J.K.; Bull, R.C. and Butler, J.E. (1981): Uterine infection in the post partum cow. II possible synergistic effect of Fusobacterium and Corynebacterium pyogenes. Theriogenoloy, 15: $573-580$.

Rukkwamsuk, T.; Wensing, T. and Krwp, T.A. (1999): Relationship between triacylglycerol concentration in the liver and first ovulation in postpartum dairy cows. Theriogenology. Apr 15; 51(6) 1133 - 1142.

Sabry, H.A.; Shalaby, S.L. and Hassan, S.G. (1997): Retained placenta in an imported Friesian herd under Egyptian condition. Vet. Med. J., Giza, 45: 121 - 127. 
Scott, H.M.; Schouten, M.J.; Gaiser, J.C.; Belschner, A.P. and Jordan, E.R. (2005): Effect of intrauterine administration of ceftiofur on fertility and risk of culling in post parturient cows with retained fetal membranes. Twins, or both. J. Am. Vet. Med. Assoc. 15; 226(12): $2044-2052$.

Snedcor, G.W. and Cochran, W.G. (1982): Statistical methods, $8^{\text {th }}$. Edition. The Iowa State. University press, USA.

Srinivas, T.K.; Subramanyam, N.; Brahmaiah, K.V.; Chandra, T.S.; Sekhara, R. and Ravikumar, P. (1999): Retained fetal membranes in crossbred Jersey cows, hematological and biochemical study. Ind. Vet. J., 3(76): $233-238$.

Tietz, N.W. (1994): Textbook of clinical chemistry, $2^{\text {nd }}$ ed. WB. Saunders Co., philadelphia, P. A, P 851.

Trinder, P. (1969): Enzymatic colorimetric method for determination of glucose. Ann. Clin. Biochem., 6: 24 - 27.

Van den Bogaad, A.E.; Hazen, M.J. and Kriele, C.P. (1992): Rationale for treatment of retained placenta in cows with neomycin and metronidazole. Vet. Rec. 18; 130(16): 349 - 350.

Younis, E.E. (1990): Nature of puerperium and its role in fertility in cows and Buffaloes. M. V. Sc. Thesis, Fac. Vet. Med., Zag. Univ. 